\title{
Characterization of Grey Water to Assess its Feasibility for Irrigation
}

\author{
Prarthana P. Hazarika ${ }^{1 *}$, B.K. Medhi ${ }^{2}$, R.K. Thakuria ${ }^{2}$, D.K. Patgiri ${ }^{1}$ and Kanku Deka ${ }^{3}$ \\ ${ }^{1}$ Department of Soil Science, Assam Agricultural University, Jorhat, Assam, India \\ ${ }^{2}$ AICRP on Irrigation Water Management, Assam Agricultural University, Jorhat, \\ Assam, India \\ ${ }^{3}$ Krishi Vigyan Kendra, Baksa, Assam, India \\ *Corresponding author
}

\begin{tabular}{|l|}
\hline Ke y w o r d s \\
$\begin{array}{l}\text { Assam, Characterization, } \\
\text { Grey water, Quality } \\
\text { parameters, ICMR/ BIS, } \\
\text { WHO }\end{array}$ \\
\hline Article Info \\
\hline $\begin{array}{l}\text { Accepted: } \\
10 \text { September } 2018 \\
\text { Available Online: } \\
10 \text { October } 2018\end{array}$ \\
\hline
\end{tabular}

A B S T R A C T

\begin{abstract}
Water availability for agriculture in the country is projected to go down to around 70 per cent by 2025 which undoubtedly will limit the country's capacity to provide expected food security. Under this water crisis scenario, grey water - an alternate source to supplement the overall water use is the need of hour. Characterization of grey water with special reference to key water quality parameters signifies immense importance for further reutilization so far the water productivity is concerned. A study was conducted at Assam Agricultural University on characterization of grey water in order to assess its feasibility to reuse, where grey water was collected during the month of February, 2017 from 10 different sites within the campus, viz. Hostel 1, Hostel 2, Hostel 3, Hostel 4, Hostel 10, Hostel 11, Hostel 12, Hostel 14, New Professors' Colony and International Girls' hostel to observe 14 key quality parameters. Variations of total $\mathrm{N}$ were found to confine below the ideal value $(<45 \mu \mathrm{g} / \mathrm{ml})$ while, $\mathrm{NO}_{3}-\mathrm{N}$ varied within the ideal $(2 \mu \mathrm{g} / \mathrm{ml})$ and permissible $(10 \mu \mathrm{g} / \mathrm{ml})$ limit of ICMR/BIS standard. Phosphate concentrations mostly trended below the ideal value $(2 \mu \mathrm{g} / \mathrm{ml})$ while total soluble solids (TSS) varied far below the acceptable ideal standard of EPA $(500 \mathrm{mg} / \mathrm{L})$. Biochemical Oxygen Demand (BOD) transcended the recommended permissible limit $(5 \mu \mathrm{g} / \mathrm{ml})$ and $\mathrm{pH}$ varied below the permissible (8.5) limit of BIS. Electrical Conductivity surpassed the recommended permissible limit attaining its maximum value of $1.13 \mathrm{mS} / \mathrm{cm}$ at Hostel 11. Sulphate and Chloride content for all selected sites found to confine below the ideal value as recommended by ICMR/ BIS. Both carbonate and bicarbonate were found ranging within permissible limit $(100 \mu \mathrm{g} / \mathrm{ml})$ while, Alkalinity averaged over the ten observed sites was found far below the ideal $(120 \mu \mathrm{g} / \mathrm{ml})$ value. Based on the recommended guideline for concentrations of fluoride, mean fluoride over the locations was found within the recommended range with exceedingly higher value (> $1.5(\mu \mathrm{g} / \mathrm{ml})$ observed in Hostel 2, Hostel 3 and Hostel 12. Arsenic in grey water with a mean value of $30.43 \mu \mathrm{g} / \mathrm{l}$ varied from 13 to $53 \mu \mathrm{g} / \mathrm{l}$ was found to exceed the threshold level (> $10 \mu \mathrm{g} / \mathrm{l}$ ) recommended by WHO.
\end{abstract}

\section{Introduction}

The demand for water is increasing day by day due to increased industrialization, population explosion, climate change and indiscriminate exploitation of water resources. This demand is posing a great challenge invoking the search of strategies for sustainable use of water, 
which calls for the use of rainwater, greywater and various other types of wastewater. Due to paucity of clean supply of water, efforts are now to undertake pragmatic alternative of meeting water needs for agriculture and allied sectors more particularly for irrigation so as to improve water productivity and development of sound water management policy. Considering the impounded pressure on freshwater resource for irrigation in crops and other uses like animal husbandry, fisheries etc. besides potable purpose among others; there is strategic need to reduce this pressure and therefore our effort is to search for other alternative source of water. In this direction, greywater, the relatively clean domestic waste water with the minimal input of excreta, derived from bathrooms, kitchen and laundry water might have enough potential to serve reducing this pressure. Recently, utilization of greywater has led to an increased interest in many parts of the world. The reuse of greywater has drawn attention to policy discussions on the face of stressed freshwater sources, on-going development goals, and the growing need for environmental protection. The physical as well as chemical properties vary from household to household and depend on different factors, such as availability of water and lifestyle of households. Compared to black water, which has the input of excreta, the scope of exploring the use of grey water in diversified activities of agriculture and allied sectors is reported to be more extensive with fruitful results in present day agriculture. As 50-80 per cent of residential wastewater is generally grey water, therefore there is enough opportunity to exploit such potential greywater reserve in supplementing water demand for different sectors as an economic and resource conservation component of the integrated water resources management more particularly in water deficit areas. Another aspect of grey water is the maintenance of water quality requirement for irrigation based on physico-chemical and microbiological characterization which determines their effective use for further exploitation for irrigation. Characterization of quality of greywater will determine how it can be reused for productive purpose. In Assam, about 24340 lakh litre of greywater is wasted every day. Effort therefore should be to evaluate viable strategy for further reutilization of this potential resource. The development of appropriate technical and policy options for grey water offers great promise for the foreseeable future.

\section{Materials and Methods}

\section{Greywater collection}

A greywater collection system was installed on the drains of bathroom/ kitchen sinks, showers, tubs, and washing machines from each of the collection sites. In each case, greywater was allowed to travel down into the drain on which greywater samples were collected. A total of ten (10) representative samples of raw grey water from ten (10) different sites viz. Hostel 1, 2, 3, 4, 10, 11, 12, 14, New Professor's Colony and International Girl's Hostel within the campus of Assam Agricultural University, Jorhat were collected. Each sample was drawn alternatively at $3^{\text {rd }}$ day of the month of February'17 and transported to laboratory for analysis and characterized based on their quality parameters. The grey water so collected was stored in large sized $(2.5 \mathrm{~L})$ borosilicate glass beakers and tested for water quality parameters. In the event of the samples to be preserved, it was stored in covered beaker at $4^{0} \mathrm{C}$. However, maximum effort was taken to get the samples analyzed within $24 \mathrm{hrs}$ of the storage.

\section{Laboratory analysis}

Physico-chemical properties of the greywater were determined for the selected parameters 
viz. Total Nitrogen, Nitrate, Orthophosphate, Total Suspended Solids (TSS), Biochemical Oxygen Demand (BOD), $\mathrm{pH}$, Electrical Conductivity (EC), Sulphate $\left(\mathrm{SO}_{4}{ }^{2-}\right)$, Chloride, Carbonate $\left(\mathrm{CO}_{3}{ }^{2-}\right)$, Bi-carbonate $\left(\mathrm{HCO}_{3}{ }^{1-}\right)$, Alkalinity, Fluoride and Arsenic. The parametric analyses of raw greywater were done as per the standard methods outlined by various authors.

\section{Total Kjeldahl Nitrogen (TKN)}

TKN was measured by digesting the samples as per the modified Kjeldahl digestion method (Jackson, 1973)

\section{Nitrate Nirogen}

Nitrate was determined by Digestion and distillation method (Jackson, 1973)

\section{Phosphate}

Orthophosphate was measured using the ascorbic acid EPA-accepted method using double beam visible spectrophotometer (HACH, 1992)

\section{Total Suspended Solids (TSS)}

TSS was measured by the method described by Baruah and Barthakur, (1999).

\section{Biochemical Oxygen Demand (BOD)}

Biochemical Oxygen Demand was measured using Standard Method 5210 B (American Public Health Association, 1992). This method employs determination of dissolved oxygen before and after a 5-day incubation period.

pH

$\mathrm{pH}$ of the raw greywater sample was measured using the $\mathrm{pH}$ meter. $\mathrm{pH}$ meter is first calibrated with known solutions of $\mathrm{pH} 4$ and 7 (Jackson, 1973).

\section{Electrical Conductivity (EC)}

Electrical conductivity of the water samples was determimed using Systronic conductivity meter (Baruah and Barthakur, 1999). Conductivity meter consists of an electrode which when immersed in the sample gives reading in $\mathrm{mS} / \mathrm{cm}$.

The conductivity meter works at a temperature of $27^{0} \mathrm{C}$.

\section{Sulphate}

Sulphate was estimated by Turbidometric method (Baruah and Barthakur, 1999) based on the precipitates of barium-sulphate in presence of sodium chloride, hypochloric acid and glycerol.

\section{Chloride}

The chloride content was determined by titrating with silver nitrate using potassium dichromate indicator (A.O.A.C, 1950).

\section{Carbonate, bicarbonate $\left(\mathrm{CO}_{3}{ }^{2-}, \mathrm{HCO}_{3}{ }^{1-}\right)$ and alkalinity}

$\mathrm{CO}_{3}{ }^{2-}, \mathrm{HCO}_{3}{ }^{1-}$ and alkalinity content were evaluated by acidimetric titration in presence of phenolophthalin indicator (Baruah and Barthakur, 1999).

\section{Fluoride}

Fluoride was determined by ion selective electrode method (A.O.A.C., 1950)

\section{Arsenic}

Arsenic content was estimated by following potassium iodide method (Dhar et al., 2004) 
In order to observe the relationships among the 14 above variables, a multiple correlations was worked out using SPSS statistical package which envisaged their degree of relationships in inferring the influence of one variable over the other(s).

\section{Results and Discussion}

Characterization of greywater in respect of key water quality parameters particularly for Total Nitrogen, Nitrate, Orthophosphate, Total Suspended Solids (TSS), Biochemical Oxygen Demand (BOD), pH, EC, Sulphate, Chloride, Carbonate, Bi-carbonate, Fluoride, Alkalinity, Arsenic over ten different locations within the AAU campus and Location wise key parameters are depicted in Table 1 and 2.

Results revealed that total nitrogen and nitrate nitrogen content ranged from a minimum value of $9 \mu \mathrm{g} / \mathrm{ml}$ and $2 \mu \mathrm{g} / \mathrm{ml}$ in site 9 , respectively to the maximum of $22 \mu \mathrm{g} / \mathrm{ml}$ in site 1 for total nitrogen and $8 \mu \mathrm{g} / \mathrm{ml}$ for $\mathrm{NO}_{3}-\mathrm{N}$ in site 10. The trend from the highest to the lowest concentrations for both the parameters with respect to their locations were Site 1> Site 10> Site 6> Site 7> Site 3> Site 4> Site 5> Site $8 \& 2>$ Site 9 for total nitrogen and Site 10> Site 1> Site 3> Site 2, 5, $6 \& 8>$ Site $4,7 \& 9$ for $\mathrm{NO}_{3}-\mathrm{N}$, respectively.

In regards to phosphate concentration, it was observed that the value ranged from 0.7 to 2.7 $\mu \mathrm{g} / \mathrm{ml}$, the highest being recorded in Site 1 and the lowest in Site 9 following the trend Site 1> Site 7> Site 6> Site $2 \& 10>$ Site $4 \& 8>$ Site 3 \& 5> Site 9, with respect to their locations. Total Suspended Solids of grey water over the locations varied from 18 to $38 \mu \mathrm{g} / \mathrm{L}$. The maximum value was recorded in Site 1 and the minimum in Site 4 and 9. The descending trend with respect to locations was Site $1>$ Site 6> Site 10> Site 3>Site 7> Site $2>$ Site $8>$ Site $5>$ Site $4 \& 9$.
The Biochemical Oxygen Demand, which is the measure of dissolved oxygen needed (i.e., demanded) by aerobic biological organisms to break down organic material present in a given grey water sample ranged from 58 to 84 $\mu \mathrm{g} / \mathrm{ml}$. The highest BOD was recorded in Site 1 and the lowest in Site 2. The trend with respect to locations followed Site 1> Site 10> Site 6> Site 5> Site 9> Site 7> Site 4> Site $3>$ Site $8>$ Site 2 .

With respect to $\mathrm{pH}$ of grey water, data varied from 6.5 to 7.2, the highest being in Site 8 and the lowest in Site 6. The maximum to minimum value within the range with respect to locations observed in Site 8 followed by Site $3 \&$ 7, Site 4, Site 2, Site $1 \& 10$, Site 5, Site 9 and Site 6 . The EC, on the other hand, varied from 0.768 to $1.129 \mathrm{mS} / \mathrm{cm}$. With the highest value recorded in Site 6 and the lowest in Site 10, the EC observed in the entire locations in descending order followed the trend Site 6> Site 1> Site $8>$ Site $7>$ Site 3> Site $2>$ Site $5>$ Site $4>$ Site $9>$ Site 10.

Regarding sulphate concentration of grey water, it was observed that the value ranged from 79 to $141 \mu \mathrm{g} / \mathrm{ml}$. The Site 9showed the highest sulphate concentration with the lowest value recorded in Site 3.

The maximum to minimum concentration of sulphate within the observed range with respect to the observed locations followed the trend Site 9> Site 6> Site $1 \&$ 10> Site 5> Site 7> Site $2 \& 4>$ Site 3.

Chloride beyond the desirable level may act as potential pollutants for grey water. In the present study, the value ranged from16 to $71 \mu \mathrm{g} / \mathrm{ml}$ with its maximum concentration recorded in Site 9 and the minimum in Site 2. The trend from highest to lowest concentration over the locations followed Site 9> Site 5> Site 7> Site 6> Site 3> Site 8> Site10> Site 1> Site 4> Site 2. 
Alkalinity, that indicates ability of water to neutralize acid pollution from grey water, is primarily governed by the bases of carbonate and bicarbonate and occasionally by hydroxides, borates, silicates, phosphates, sulphides and organic ligands.

Alkalinity in grey water ranged from 43 to 76 $\mu \mathrm{g} / \mathrm{ml}$, following the trend of Site $8>$ Site 3> Site 9> Site 7> Site $5 \&$ 6> Site 1> Site 10> Site $4>$ Site 2.

The carbonate concentration in the present investigation varied from 12 to $66 \mu \mathrm{g} / \mathrm{ml}$ with the highest value recorded in Site 9 and the lowest in Site 8 and followed a trend of Site 9> Site $5 \&$ 7> Site 4> Site 3> Site 6> Site 2> Site 10> Site $8>$ Site 1. Regarding bicarbonate concentration in grey water, it varied from 22 to $44 \mu \mathrm{g} / \mathrm{ml}$, the highest being observed in Site 1 and the lowest in Site 9. The concentrations with respect to locations in descending order were: Site 5 \& 7> Site 4> Site 1> Site 9> Site 8> Site 3> Site 6> Site 2> Site10.

Fluoride being considered as one of the significant water pollutant, has now-a-days become an emerging issue. It was observed from the present study that the Fluoride concentration ranged from 0.9 to $2.2 \mu \mathrm{g} / \mathrm{ml}$ and the maximum concentration was seen in Site 3 and the minimum in Site $5 \& 10$ with a trend in descending order like: Site $3>$ Site 2> Site 7> Site $4 \& 8>$ Site 6> Site 1> Site 9> Site $5 \& 10$.

With respect to Arsenic (No. 1 Carcinogen) concentration, results revealed variation of 13 to $53 \mu \mathrm{g} / \mathrm{l}$, the highest concentration was recorded in Site 5 and the lowest in Site 1. The descending concentrations with respect to locations followed the trend Site 5> Site 3> Site 6> Site $4 \& 10>$ Site $9>$ Site $8>$ Site $2>$ Site $7>$ Site1.

Table.1 Characteristics of grey water on certain key water quality parameters

\begin{tabular}{|l|l|l|l}
\hline Sl. No. & Parameters & Mean \pm SD & Range \\
\hline 1 & Total Nitrogen $(\mu \mathrm{g} / \mathrm{ml})$ & $15.70 \pm 4.32$ & $9-22$ \\
\hline 2 & Nitrate $(\mu \mathrm{g} / \mathrm{ml})$ & $3.70 \pm 2.00$ & $2-8$ \\
\hline 3 & Phosphate $(\mu \mathrm{g} / \mathrm{ml})$ & $1.23 \pm 0.59$ & $0.7-2.7$ \\
\hline 4 & TSS $(\mathrm{mg} / \mathrm{L})$ & $24.70 \pm 6.70$ & $18-38$ \\
\hline 5 & BOD $(\mu \mathrm{g} / \mathrm{ml})$ & $69.60 \pm 7.60$ & $58-84$ \\
\hline 6 & pH & $6.87 \pm 0.23$ & $6.5-7.2$ \\
\hline 7 & EC $(\mathrm{mS} / \mathrm{cm})$ & $0.99 \pm 0.11$ & $0.768-1.129$ \\
\hline $\mathbf{8}$ & Sulphate $(\mu \mathrm{g} / \mathrm{ml})$ & $108.60 \pm 23.19$ & $79-141$ \\
\hline $\mathbf{9}$ & Chloride $(\mu \mathrm{g} / \mathrm{ml})$ & $45.10 \pm 17.25$ & $16-71$ \\
\hline 10 & Carbonate $(\mu \mathrm{g} / \mathrm{ml})$ & $49.80 \pm 17.62$ & $12-66$ \\
\hline 11 & Bi-carbonate $(\mu \mathrm{g} / \mathrm{ml})$ & $33.90 \pm 7.66$ & $22-44$ \\
\hline 12 & Alkalinity $(\mu \mathrm{g} / \mathrm{ml})$ & $56.10 \pm 10.12$ & $43-76$ \\
\hline 13 & Fluoride $(\mu \mathrm{g} / \mathrm{ml})$ & $1.39 \pm 0.42$ & $0.9-2.2$ \\
\hline 14 & Arsenic $(\mu \mathrm{g} / \mathrm{L})$ & $30.40 \pm 12.84$ & $13-53$ \\
\hline
\end{tabular}


Table.2 Key water quality parameters of grey water over the selected sites

\begin{tabular}{|c|c|c|c|c|c|c|c|c|c|c|c|c|c|c|c|}
\hline Sites & Locations & TN & $\mathrm{NO}_{3}-\mathrm{N}$ & $\mathrm{PO}_{4}$ & TSS & BOD & pH & EC & $\mathrm{SO}_{4}$ & Cl & $\mathrm{CO}_{3}$ & $\mathrm{HCO}_{3}$ & Alk & $\mathbf{F}$ & As \\
\hline 1 & Hostel No.1 & 22 & 6 & 2.7 & 38 & 84 & 6.8 & 1.124 & 130 & 31 & 12 & 38 & 51 & 1.2 & 13 \\
\hline 2 & Hostel No.2 & 12 & 3 & 1.1 & 21 & 58 & 6.9 & 0.987 & 85 & 16 & 48 & 26 & 43 & 1.9 & 19 \\
\hline 3 & Hostel No.3 & 17 & 5 & 0.8 & 28 & 66 & 7.1 & 1.021 & 79 & 48 & 58 & 30 & 69 & 2.2 & 41 \\
\hline 4 & Hostel No.4 & 14 & 2 & 1 & 18 & 67 & 7 & 0.897 & 85 & 30 & 60 & 41 & 48 & 1.4 & 37 \\
\hline 5 & Hostel No.10 & 13 & 3 & 0.8 & 19 & 72 & 6.7 & 0.956 & 112 & 68 & 64 & 44 & 53 & 0.9 & 53 \\
\hline 6 & Hostel No.11 & 19 & 3 & 1.4 & 31 & 74 & 6.5 & 1.129 & 132 & 49 & 54 & 28 & 53 & 1.3 & 38 \\
\hline 7 & Hostel No. 12 & 18 & 2 & 1.7 & 25 & 69 & 7.1 & 1.025 & 94 & 57 & 64 & 44 & 58 & 1.6 & 16 \\
\hline 8 & Hostel No. 14 & 12 & 3 & 1 & 20 & 60 & 7.2 & 1.1 & 98 & 42 & 28 & 32 & 76 & 1.4 & 22 \\
\hline 9 & New Professor Colony & 9 & 2 & 0.7 & 18 & 70 & 6.6 & 0.889 & 141 & 71 & 66 & 34 & 61 & 1.1 & 28 \\
\hline 10 & International Girls Hostel & 21 & 8 & 1.1 & 29 & 76 & 6.8 & 0.768 & 130 & 39 & 44 & 22 & 49 & 0.9 & 37 \\
\hline
\end{tabular}

*The units are same as table 1

In the present study grey water collected from ten locations of Assam Agricultural University, Jorhat campus was characterized based on its 14 key water quality parameters. The mean and range of each parameter in grey water varied orienting their values with reference to the recommended guidelines of national and international standards as set by ICMR/ BIS/ EPA.

In respect of total nitrogen, it varied from 9 to $22 \mu \mathrm{g} / \mathrm{ml}$ with a mean value $15.70 \mu \mathrm{g} / \mathrm{ml}$ and found to retain their content below the ideal value of $45 \mu \mathrm{g} / \mathrm{ml}$. In most of the grey water nitrogen content is governed by the levels of reduction of nitrate, nitrite, ammonia and organic nitrogen forms which might otherwise be regulated by the amount of total suspended solids. Similar results relating the total nitrogen content with TSS was earlier reported by Wang et al., (2015). In regard to nitrate nitrogen it ranged from 2 to $8 \mu \mathrm{g} / \mathrm{ml}$ with mean value $3.25 \mu \mathrm{g} / \mathrm{ml}$ and found to confine within the recommended permissible $(10 \mu \mathrm{g} / \mathrm{ml})$ limit. This availability of nitrate in grey water is attributed to be governed by the oxidation of ammonical and nitrite form which is highly soluble and remains stable for longer period of time. Variation of nitrate nitrogen in relation to TSS in waste water was earlier reported Michael R. Rosen (2003)
Phosphate in grey water with its mean and range of $1.23 \mu \mathrm{g} / \mathrm{ml}$ and $0.7-2.7 \mu \mathrm{g} / \mathrm{ml}$ across the locations had concentration below the ideal value of $2 \mu \mathrm{g} / \mathrm{ml}$. The lower value might be discussed in the light of quantity-intensity factor of phosphate which owing to presence of suspended solid led to increase the adsorption (quantity) at the cost of decrease in solution phosphate (intensity) concentration in grey water (Jones, 2008).

Total Suspended Solids which reflected the overall deposition of suspended particles in grey water varied from $18-38 \mu \mathrm{g} / \mathrm{ml}$ with mean value $24.70 \mu \mathrm{g} / \mathrm{ml}$ and found to be far below the ideal value as recommended by EPA $(500 \mathrm{mg} / \mathrm{L})$. The TSS content of grey water is largely influenced by the original source of water along with the use pattern of habitants. The wide variability of TSS content as affected by the use pattern of habitants was reported by Eriksson et al., (2002) and AlJayyousi (2003)

The Biochemical Oxygen Demand, which is the measure of dissolved oxygen needed (i.e. demanded) by aerobic biological organisms to break down organic material present in a given grey water sample, ranged from 58 to $84 \mu \mathrm{g} / \mathrm{ml}$ with its mean value $69.60 \mu \mathrm{g} / \mathrm{ml}$ surpassed the guideline value $(>5 \mu \mathrm{g} / \mathrm{ml})$ as 
recommended by BIS. The higher BOD value of grey water was due to higher demand of oxygen in water and vice-versa. The transcended value of BOD might be attributed to the increased demand of oxygen for microbial decomposition of suspended solids present in grey water. The result was in conformity with the findings supported by Patel et al., (1983), Morel and Diener (2006), Li et al., (2009) and Edwin et al., (2014)

$\mathrm{pH}$, an indicative parameter to define the extent of acidity and alkalinity of grey water, was found to vary from 6.5 to 7.2 with a mean of 6.87 which suggested values tended towards slight acidity. This might probably be due to use shampoos by the inhabitants, the $\mathrm{pH}$ of which actually found to confine from slight acidic to near neutral. The results were in close conformity with the findings outlined by Li et al., (2009), Morel and Diener (2006), Raude et al., (2009)

Electrical conductivity that ranged from 0.768 to $1.13 \mathrm{mS} / \mathrm{cm}$ with mean value of 0.99 $\mathrm{mS} / \mathrm{cm}$ was found to be above the permissible value of $0.8 \mathrm{mS} / \mathrm{cm}$. This might be attributed to dissolution of salts like carbonates and bicarbonates of calcium, magnesium, sodium and chloride producing positively and negatively charged ions which conduct electricity in relation to their concentration. This could be supported by the works published by Maiga et al., (2013) and Jeppesen, 1996

Chloride and Sulphate content for all the selected sites of grey water found to confine far below the ideal value as recommended by ICMR/ BIS. Chloride content with its mean $45.10 \mu \mathrm{g} / \mathrm{ml}$ varied from $16-71 \mu \mathrm{g} / \mathrm{ml}$. As the chloride level found to be far below the recommended standard, therefore infection level of all the grey water samples was likely to be towards higher side. Winward et al., (2008) reported that chloride being a strong disinfectant when its concentration is high the level of infection will be less and vice-versa. Lower value of sulphate might be due to low level of sodium lauryl sulphate used commonly as surfactant for cleaning products, cosmetic and personal care product (Braga et al., 2014).

In regard to carbonate and bicarbonate content of grey water, both was found to vary within the permissible limit $(100 \mu \mathrm{g} / \mathrm{ml})$. Likewise alkalinity, which is again considered to be influenced by dissolved carbonate and bicarbonate content, was found to be far below the ideal $(120 \mu \mathrm{g} / \mathrm{ml})$ recommended value. The variations of these parameters might be associated with the consumption pattern of water by the inhabitants. Similar observations were reported by Ledin et al., (2001) and Devi et al., (2017)

Fluoride in all the grey water samples was found ranging from sub-optimal to close to higher level. Higher concentration of fluoride might be attributed to higher fluoride content in tooth pastes, soaps etc. used by the habitants which got release from washing basins, bath room water etc. The low concentration of fluoride might be due to dilution effect of effluent grey water. The result was found in conformity with the published work by Bouwer (1991).

In all the selected locations, grey water arsenic concentration varied from 13 to 53 $\mu \mathrm{g} / \mathrm{l}$ with mean value $30.43 \mu \mathrm{g} / \mathrm{l}$ inferring that all the samples exceeded the permissible limit as set by WHO. The higher arsenic concentration in grey water might probably be due to use of every day products used by habitants and increased concentration of original water source (Tjandraatmadja et al., 2008). Shankar et al., (2014) reported that higher concentration of arsenic at source of groundwater has immense role in increasing the toxic level of arsenic. 
The characterization results obtained in this study has provided information on the inherent variability of greywater quality from sites. Grey water characteristics are highly variable as they depend on source of water, the day to day living standards the activities and habits of the residents. Grey water characterization with respect to key quality parameters help categorizing their suitability based on recommended guidelines for further reuse. The characteristics of the greywater obtained in this investigation conducted indicate the necessity of treatment prior to disposal into the environment or for reuse in irrigational purpose.

\section{References}

Al-Jayyousi, O. R., 2003. Grey water Reuse: Towards Sustainable Water Management: Desalination. 156 (13):181-192.

Anonymous. 1992. Hach water analysis handbook. 2nd ed. Hach Company, Loveland, CO.

Anonymous. 1992. Standard methods for the examination of water and wastewater. $18^{\text {th }}$ ed. American Public Health Association, Washington, DC.

AOAC.1950. Association of Official Agricultural Chemist Publication.

Baruah, T.C. and Barthakur, H.P.1999. A Text Book of Soil Analysis. Vikas Publ. House Pvt Ltd., New Delhi.

Bouwer, H. 1991. Ground Water Research with Sewage Effluent. Water Science Technology. 23: 2099-2108.

Braga, J.K. and Varesche, M.B.A. 2014. Commercial Laundry Water Characterisation. American Journal of Analytical Chemistry. 5: 8-16.

Devi, R.C. and Nirmala Devi, D. and Shrinithivihahshinil. 2017. Removal of Physicochemical Parameters of Grey Water Using Biofiltration Techniques. International Journal of Recent
Research and Applied Studies. 4(8): 3145

Dhar, R.K., Zhenga, Y., Rubenstone, J. and Geen, A.V. 2004. A rapid colorimetric method for measuring arsenic concentrations in groundwater. Analytica Chimica Acta. 526: 203-209.

Edwin, G. A., Gopalsamy, P. And Muthu, N. 2014. Characterization of domestic gray water from point source to determine the potential for urban residential reuse: a short review. Appl. Water Sci. 4: 3949.

Eriksson, E., Auffarth, K., Henze, M. and Ledin, A. 2002.Characteristics of grey wastewater. Urban Water. 4(1): 85-104.

Jackson, M.L. 1973. Soil Chemical Analyisis. Prentice Hall of India. Pvt. Ltd. New Delhi.

Jeppersen, B. and Solley, D. 1994. Domestic Grey water Reuse: Overseas Practice and its Applicability to Australia. Research Report No 73. Urban Research Association of Australia, Brisbane City Council.

Ledin, A., Eriksson, E. and Henze, M. 2001. Aspects of groundwater recharge using grey wastewater. P. Lens, G. Zeemann and G. Lettinga (Editors), Decentralised Sanitation and Reuse, London.650.

Li, F., Wichmann, K. And Otterpohl, R. 2009. Review of the technological approaches for grey water treatment and reuses. Science of the Total Environment. 407: 3439-3449.

Maiga, Y., Moyenga, D., Ushijima, K., Sou, M. And Maiga, A.H. 2014. Greywater characteristics in rural areas of the Sahelian region for reuse purposes: The case of Burkina Faso". Revue des Sciences de l'Eau. 27(1): 39-54

Michael R. Rosen. 2003. Trends in Nitrate and Dissolved-Solids Concentrations in Ground Water, Carson Valley, Douglas County, Nevada, 1985-2001. U.S. 
Geological Survey. Water-Resources Investigations Report 03-4152

Morel, A. and Diener, S. 2006. Grey water Management in Low and MiddleIncome Countries, Review of different treatment systems for households or neighbourhoods. Swiss Federal. Institute of Aquatic Science and Technology (Eawag). Dübendorf, Switzerland. 5: 9

Patel, R.N., Bose, H.R., Mandy, W.J. and Hoare, D.S. 1972. Physiological studies of methane- and methanol-oxidising bacteria: comparison of a primary alcohol dehydrogenase from Methylococcus capsulatus (Texas strain) and Pseudomonas species M27. Journal of Bacteriology. 110: 570-577.

Raude, J.M., Mutua, B.M., Chemelil, M.C. and Sleytr, K. 2009. Characterization of Greywater from Urban and Peri-urban Areas of Nakuru Municipality, Kenya. Water, Sanitation and hygiene: Sustainable Development and Multisectoral Approaches. Reviewed Paper
247. 34th international Conference, Addis Baba, Ethiopia.

Shankar, S., Shanker, U. and Shikha. 2014. Arsenic Contamination of Groundwater: A Review of Sources, Prevalence, Health Risks, and Strategies for Mitigation. The Scientific World Journal. Article ID 304524.

Tjandraatmadja, G., Pollard, C., Sheedy, C. and Gozukara, Y. 2010.Sources of Contaminants in Domestic Wastewater: Nutrients and Additional Elements from Household Products. CSIRO: Water for a Healthy Country National Research Flagship, Australia: 12 - 13.

Wang, X., Zhao-cun Liu Ji-lun and Zuo, M.N. 2015. Relationship between nutrient pollutants and suspended sediments in upper reaches of Yangtze River. Water Science and Engineering. 8(2): 121126.

Winward, G.P., Avery, L.M., Stephenson, T., and Jefferson, B. 2008. Chlorine disinfection of grey water for reuse: effect of organics and particles. Water Resources. 42 (1-2): 483-91.

\section{How to cite this article:}

Prarthana P. Hazarika, B.K. Medhi, R.K. Thakuria, D.K. Patgiri and Kanku Deka. 2018. Characterization of Grey Water to Assess Its Feasibility for Irrigation. Int.J.Curr.Microbiol.App.Sci. 7(10): 1056-1064. doi: https://doi.org/10.20546/ijcmas.2018.710.117 